\title{
The Role of Blended Learning on Cognitive Step in Education of Sport Teaching by Adjusting the Learning Style of the Students
}

\author{
Abi Fajar Fathoni \\ Postgraduate \\ Malang State University \\ Malang, Indonesia \\ fajarfathoniabi@gmail.com
}

\begin{abstract}
Education of sport teaching is often done by using face to face teaching where the teaching model is only effective for the students with kinesthetic learning style. However, for the students that have visual and auditorial learning style, it is less effective to use only face to face teaching. The purpose of this article to determine the level of eligibility of blended learning as a learning that is able to facilitate learners who have a diversity of three learning styles in learning sports education. The method of writing articles using meta analysis. The field of study is a component related to mixed learning in sports education. The result was that the students were interested in the blended learning and the effectiveness of the learning increased. Therefore, it is expected for the students to do the learning using blended learning. Besides doing face to face teaching, the teacher is also expected to be able to develop the teaching sources in form of video and audio to be the facility in online and offline learning that can be used for the students with visual and auditorial learning style.
\end{abstract}

Keywords - blended learning, cognitive step, education of sport teaching, learning style

\section{INTRODUCTION}

Sport teaching and learning is always close to physical activities. One of the physical activities that is usually done by students is movement learning to master a skill. Dacica (2015) stated that the function of physic and sport teaching and learning is biological, movement, psychological, and social that is related to the concept of balance and unified character development. Based on that statement, one of the functions of sport teaching and learning leads to the students' movement learning[6].

Movement learning is needed some steps to master certain skill. Makino, Ren, Liu, Kim, Kondapeneni, Liu, Kuzum, and Komiyama (2017) said that skill learning is done through three stages of sport teaching and learning, that is: (1) cognitive stage, (2) association stage, (3) automation stage[11]. In the cognitive stage, the teacher gives a material understanding to the students about a new movement in what and how it is done. The association stage is done after the students answered the cognitive questions and made an organization of effective movement pattern to produce a movement by constructing control ability and attitude consistency and self-confidence. In the automation stage, after doing the exercise, the students are leaded to the automation stage step by step, the movement have developed well and they can control the movement in a short time.

Narayana, Zhang, Rogers, Strickland, Franklin, Lancaster and Fox (2014) also mentioned that the three stages of movement learning are cognitive learning stage, association learning stager, and autonomous learning stage[15]. The transition from association to autonomous stage is marked by the movement mastery, so that it can be concluded that autonomous stage has the same meaning with automation stage.

The first stage of movement learning is cognitive stage. So, this stage can be the success of the movement learning base. If the process of cognitive stage is well done, the best result will be obtained and vice versa. Therefore, in this stage, the teacher has to facilitate the students well to obtain knowledge and information that can be understood by the students. As what stated by Kim, Edens, Iorio, Curtis, and Romero (2015) that learning and understanding needs to be strengthened by cognitive skill development to enable practice knowledge and implementation treatment[8].

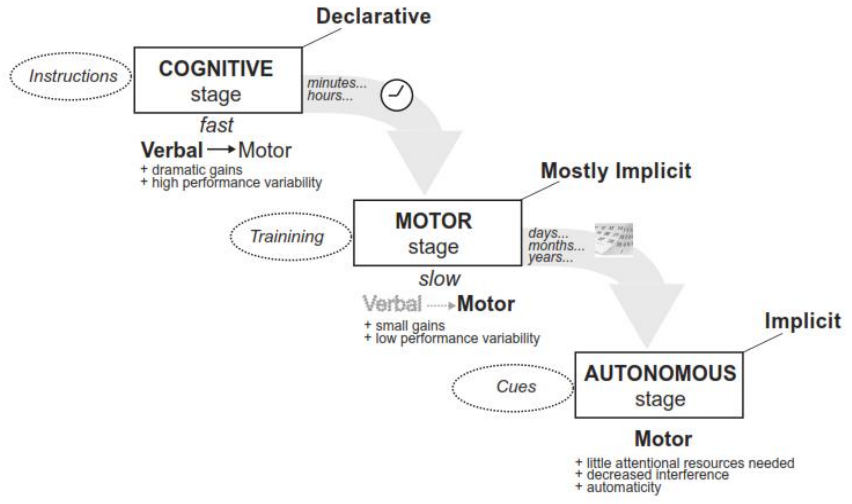

Fig. 1. The Model of Movement Learning Stages (Marinelli, Quartarone, Hallett, Frazzitta and Ghilardi, 2017)[12] 
Cognitive stage specifies the success of learning and even influences the next stages of movement learning in sport teaching and learning. That is why, when the teaching process is done, the teacher should really understand the condition and capacity of students learning. One of the important things is that the teacher should really understand the students' learning style characteristics. Rassool and Rawaf (2008) figured out that learning style covers visual, auditorial and kinesthetic learning style[21]. Those learning styles are commonly known.

Alrabah, Wu, and Alotaibi (2018) explained that students with visual learning style prefer to study by seeing[1]. It means that they have good visual memory and prefer the information presented visual, in form of diagrams, charts, maps, posters, and displays. By knowing those students' learning style, the teacher has to be able to give learning facility that is appropriate to that students' visual learning style. Brown and Palmer (2012) explained that auditorial learning style describes those who can study well through listening instruction like lecturing, discussing and recording[4]. Thus, the teacher can give learning facilities that make the students obtain information in form of sound. Asiry (2016) also explained that kinesthetic learning style is learning through touch and experience that stress in doing, physical involvement, and object manipulation[2]. For the students with this learning style, the teacher can give the lesson in form of experience and practice.

Leasa, Corebima, Ibrohim, and Suwono (2017) said that sport education is more appropriate using kinesthetic learning style, but the students are still needed to involve in several learning style, for example sport and games clues can also be in form of written and spoken[10]. For the students with kinesthetic learning style, it is no matter. They will learn more effective by given a demonstration and will learn from the participation experience in that activity. Raid's statement has a meaning that kinesthetic learning style is not always appropriate in teaching sport. There may be some students with visual or auditorial learning style. By considering various kinds of the students' learning style, the teacher is expected to be able to create learning atmosphere that leads to visual, auditorial, and kinesthetic learning style.

Nowadays, there is an innovative teaching called blended learning. One of the purposes of blended learning is to facilitate the students with the various learning style. It is because in blended learning, it covers several learning models that is face to face, online, and offline. Lalima and Dangwal (2017) stated that blended learning is the most logic and natural evolution of our teaching agenda[9]. It shows the elegant solution for the challenge in making teaching and individual needs appropriate. It is an opportunity to integrate the development of innovation and technology that is offered by online learning using interaction and participation offered by the best traditional learning.

It is mentioned that online teaching and learning is a part of blended learning. Online teaching and learning is the teaching and learning that leads to the students to access learning resources using internet access or the students can interact with the teacher using internet. If the teacher has no time to interact with the students, the teacher can provide the relevant learning resources to be accessed by the students later. It is in line with the statement of Ugurlu (2013) that online teaching and learning enables the students to access multimedia online that contains video or audio related to the material to learn anywhere and anytime[24]. Beside it can be accessed online like what Ugurlu said, the material provided can be downloaded and taken as offline teaching material if sometimes the internet access cannot be connected.

In line with the implementation of online teaching, many teachers consider that by implementing online teaching, the learning objectives will not achieve effectively. The reason is that technology facilities used in the teaching and learning process will distract the students' attention to do negative activity rather than using it to access learning material. However, Chen (2015) states that in the development of this era, it is not the technology that is used as a negative reason but the user's policy, that is the students, so that teachers should be able to direct and control the students to use the technology available for learning activities[5]. Matukhin and Zhitkova (2015) the use of new information technology tools contributes to the humanization of the teaching and learning process[13]. These statements imply that the inevitable progress of the time can be done to remain wisdom in self-conditioning of times. So is learning that uses a variety of advanced facilities today. The use of technology will actually contribute positively for education. In order to make these technologies can be controlled, the teachers attempt to create a system so that the use of the technology can achieve the goal of learning effectively.

In addition to online and offline learning combined in blended learning, there is also face-to-face learning. Face-toface learning is often referred to traditional learning. Millan, Semer, Rodrigues and Gianini (2012) suggest that learning by traditional methods is done face-to-face between students and teacher where the teacher monitors and controls the learning directly[14]. Such traditional or face-to-face lessons can be used in clarifying the students' understanding while learning by using online and offline teaching materials, giving the students the opportunity to inquire about the material that have learned and also face-to-face lessons used for practice by using the understanding when they learn online and offline.

Thus, blended learning which includes online learning, offline and face to face can facilitate all students who have a variety of learning styles on sport teaching and learning. Online and offline learning is expected to facilitate the students who have visual and auditorial learning styles. Because in online and offline learning, it provides learning media in form of a video that contains a motion of skills and also given explanatory sounds related to the movement of skills learned by the students. Then, in face-to-face learning, the learning materials are strengthened by the presence of the teacher with the understanding of the students obtained while learning online and offline.

In this article, the researcher discussed and analyzed the process of sports teaching and learning at the cognitive stage by adjusting the students learning style. For example, by implementing blended learning in sports teaching and learning, the instructional materials in form of multimedia are given to 
the students and the application of learning systems is online and offline. Then, it will be known how effective the process is and how the responses from various parts related to each others.

\section{MATERIALS AND METHODS}

The method of writing this article is by using meta analysis. Meta-analysis is one of the efforts to summarize the various research results quantitatively. Meta-analysis as a technique intended to re-analyze the results of research. Sources obtained from some research results because they are considered as primary data collectors. The subject of the study is the parties involved in learning sports education such as teachers, lecturers, students and students of sports education. The field of study includes various components related to blended learning in sports education such as blended learning support media, blended learning system and blended learning model.

\section{RESULT AND DISCUSSION}

The research related to blended learning in the learning process has been done a lot. But in this article, it will be studied about the results of research on the application of blended learning associated with sport teaching and learning. The following will be presented some research results of the application of blended learning on learning sports education.

The first study was related to the learning of blended learning based badminton courses conducted at PGRI University Banyuwangi Study Program of Education of Physical Sport and Health. The research was conducted by developing the instructional materials for online and offline learning which contains about all badminton material. Then, the teaching materials were used in learning activities in badminton courses. After the learning activities conducted in several meetings, the researcher took the data related to attractiveness, clarity, ease, and effectiveness. In addition, students were also given several times of test to measure the level of effectiveness and efficiency of the learning.

The criteria of attractiveness reached a percentage of $82.36 \%$. On the clarity criteria, it reached a percentage of $81.33 \%$. On the criteria of ease, it reached the percentage equal to $82,08 \%$. In the criteria of effectiveness, it reached percentage of $83.33 \%$. The overall average was obtained at $82.18 \%$. Based on the average data, Sandi (2017) states that the development of learning based on blended learning based badminton courses is very valid[22].

The second research was the tennis learning by using interactive multimedia which is done by the students of Physical Education and Health Department of State University of Malang. The research was conducted with an interactive multimedia development step that contains all the tennis materials. Then, the interactive multimedia was used in the learning activities of tennis course as students' learning materials. After the learning activities conducted in several meetings the researcher collected the data related to attractiveness, ease, clarity, feasibility and accuracy. Students were also given pre-test and post-test to measure the level of effectiveness of the interactive multimedia that had been developed.

In the criteria of the interactive multimedia attractiveness, it was obtained the percentage of $95.1 \%$. In the criteria of the interactive multimedia ease, it was obtained the percentage of $92.2 \%$. In the criteria of the interactive multimedia clarity, it was obtained the percentage of $93.9 \%$. In the criteria of interactive multimedia feasibility, it was obtained the percentage of $95 \%$. In the criteria of interactive multimedia suitbility, it was obtained the percentage of $94.1 \%$. Then, from all the data, it was obtained the average percentage of $93.6 \%$. From that average, Raibowo (2017) stated that interactive multimedia which contains subject matter in the tennis lesson is very valid and can be used as learning materials for students[20].

In addition to the data related to students' responses to interactive multimedia used in learning tennis courses, it was also obtained pre-test and post-test data from the students. The data consisted of normality test and paired-test data to know the effectiveness of the interactive multimedia developed. Furthermore, the average of pre-test 64 is less than the average of post-test 80. Thus, Raibowo (2017) stated that interactive multimedia is effective for tennis learning[20].

The third study of blended learning on futsal learning. The subject of the research is the students of Physical and Health Education at State University of Malang who follow futsal subjects. The results of this study obtained data about subject responses to blended learning about futsal, learning effectiveness and learning efficiency.

The result of the research is $87 \%$ of subjects stated that blended learning futsal has several eligibility criteria. These criteria include clarity, conformity, suitability, easy and attractiveness. So blended learning about futsal is valid and feasible to be used in learning process. Then the researchers to test the effectiveness of learning measured through pre-test and post-test. The data obtained is processed by using statistical calculation. The result Baidhori (2017) states that blended learning in futsal subject can improve learning outcomes[3].

Subsequent research on learning media used in blended learning Physical Education. Research is done by developing teaching materials for face-to-face, offline and online learning. Then the teaching materials used by subject of eleven grade students SMK N 3 Boyolangu Tulungagung as many as 30 people. Once used in learning, students respond to blended learning materials used in physical education. the feasibility of blended learning materials in physical education learning obtained a percentage of $89.03 \%$. So Putra (2017) states that blended learning material on Physical Education is worth to be used[18].

Further research is about teaching materials in the form of interactive multimedia used in blended learning. Multimedia interactive contains swimming material and research done to the student of Physical Education and Health Education of State University of Malang. From the research results obtained average percentage of $93.19 \%$. So Setyawan (2017) stated that interactive multimedia for mixed learning is suitable for use in pool learning[23]. 
TABLE 1: FINDING DATA FROM RESEARCH

\begin{tabular}{|c|c|c|c|c|c|c|c|c|c|}
\hline \multirow{2}{*}{ Researchers } & \multicolumn{9}{|c|}{ Aspect } \\
\hline & Attractiveness & Clarity & Ease & Feasibility & Suitability & Conformity & Benefits & Effectiveness & Efficiency \\
\hline Sandi (2017) & $82,36 \%$ & $81,33 \%$ & $82,08 \%$ & & & & & $\begin{array}{l}\text { The first meeting was } \\
75.6 \% \text { (thoroughly } \\
\text { complete) } \\
\text { The second meeting } \\
\text { was } 81.2 \% \text { (very } \\
\text { complete) } \\
\text { The third meeting } \\
\text { was } 82.4 \% \text { (very } \\
\text { complete) }\end{array}$ & $\begin{array}{l}\text { The first meeting is } \\
547,08 \text { seconds } \\
\text { The second meeting is } \\
543.44 \text { seconds } \\
\text { The third meeting is } \\
517.8 \text { seconds }\end{array}$ \\
\hline $\begin{array}{l}\text { Raibowo } \\
\text { (2017) }\end{array}$ & $95,1 \%$ & $93,9 \%$ & $92,2 \%$ & $95 \%$ & $94,1 \%$ & & & $\begin{array}{l}\text { The average of pre- } \\
\text { test } 64 \text { is less than the } \\
\text { average of post-test } \\
80 \text {. }\end{array}$ & \\
\hline $\begin{array}{l}\text { Baidhori } \\
\text { (2017) }\end{array}$ & $91 \%$ & $90 \%$ & $88 \%$ & & $87 \%$ & $87 \%$ & & & $\begin{array}{l}\text { The subject is able to } \\
\text { master the material } \\
\text { within five days. }\end{array}$ \\
\hline Putra (2017) & $\begin{array}{c}\text { Textbook } \\
88,06 \%\end{array}$ & $\begin{array}{c}\text { Textbook } \\
88,83 \%\end{array}$ & $\begin{array}{c}\text { Textbook } \\
87,50 \%\end{array}$ & & & & & & \\
\hline & $\begin{array}{c}\text { Autoplay } \\
88,96 \%\end{array}$ & $\begin{array}{c}\text { Autoplay } \\
88,13 \%\end{array}$ & $\begin{array}{c}\text { Autoplay } \\
88,67 \%\end{array}$ & & & & & & \\
\hline & $\begin{array}{c}\text { Edmodo } \\
89,79 \%\end{array}$ & $\begin{array}{c}\text { Edmodo } \\
90,56 \%\end{array}$ & $\begin{array}{c}\text { Edmodo } \\
90,33 \%\end{array}$ & & & & & & \\
\hline $\begin{array}{l}\text { Setyawan } \\
(2017)\end{array}$ & $92,77 \%$ & $93,07 \%$ & $93,33 \%$ & & & & $94,16 \%$ & & \\
\hline
\end{tabular}

Face to face strategy in sport teaching and learning has limited time. While face-to-face learning should be divided into several stages such as the delivery of material, giving examples, the implementation of practice by the students and evaluation by the teachers against the practice of the students. From the stages in physical teaching and learning by using face-to-face process, it is certain that the time required should be more. But, in reality, the time given is very limited. The time is also included for heating and cooling exercises.

The students who have kinesthetic learning style will be learn maximally using face-to-face learning. However, face-toface learning will be less effective to deliver to the students with visual and auditorial learning styles. Therefore, to overcome this problem, there needs to be an additional time to learn outside face-to-face learning time. Learning outside faceto-face learning time should be appropriate to the learning needs of the students who have visual and auditory learning styles. So, it is possible for learning outside the face to face learning time to be done with the teaching video and audio materials facilities.

Seeing the problem about the needs of learning models such as learning model needs, then blended learning can be a solution to solving the problem. Blended learning is appropriate as a problem solver because blended learning is a mixture of several learning models ie face-to-face, online and offline. On online and offline learning, it can be done outside of face-to-face learning time or anywhere. Learning online and offline can be given as a teaching materials in form of video and audio that facilitate the students with visual and auditorial learning style.
Blended learning can be done in the present because today's technology can be a facility to do blended learning. The students in the current generation has used a variety of cuttingedge technology today. In accordance with some opinions submitted by some of the following researchers, Rahman, Hussein, and Aluwi (2015) blended learning can improve the quality of learning by attracting students and providing better platform and exposure[19]. Okaz (2015) stated that new generation comes with a digital background, thus blended learning approach can be very useful because it will improve the quality of learning and improve students' access to get the information[17]. Nazarenko (2015) said that studnets are sensitive and responsive to new technologies and this should be used to motivate them to use technology in learning[16].

The results of the research data that had been studied above showed that students' responses to blended learning and media that support the learning obtained a high percentage. It also showed that blended learning and its supporting media made the students interested. In line with the statements of Hubackova and Semradova (2016) on another study that blended learning is not only acceptable but also highly favored by students[7].

In addition, the effectiveness test in this study also showed that blended learning and the supporting media also made learning more effective. It can be proven in the result of the study that there was an increase in the test of the students related to the material being studied. Other studies also showed the effectiveness of blended learning. As stated by Yigit, Koyun, Yuksel and Cankaya (2014) that blended learning shows that learning is more effective, learners' achievements are better than expected rather than using traditional learning[25]. 


\section{CONCLUSIONS}

Sports teaching and learning is always identical with the practice of motion learning. Learning self-motion has a stage that is the stage of cognitive, associative and automation. The cognitive stage is the most fundamental stage of motion learning. At this stage students are expected to gain a lot of information and knowledge, and learn to understand. In the learning process, there are three learning styles that is visual, auditorial and kinesthetic learning style. Sport teaching and learning is less effective if it is only done using face-to-face learning because face-to-face learning is only effective for the students that have kinesthetic learning style. In addition, limited time also affects the effectiveness of learning. While the students who have visual and auditory learning styles also require a sufficient time to learn.

Todays, the development of blended learning combines learning face to face, online and offline. Learning is not only done face to face but also can be done online and offline. Online and offline learning can be done by learners beyond face-to-face learning and can be done anywhere without the teacher. So, it can be said that this learning provides opportunities for students to learn by using the time needed. It is proven in various research that blended learning and supporting media motivate students to learn. it is also found that the effectiveness of learning is also increasing because blended learning is able to facilitate the students with three learning styles.

Face-to-face learning can be maximized for the students who have kinesthetic learning style. While the online and offline learning can be maximized by learners who have visual and auditorial learning style through materials that are packaged in the form of video and audio. Therefore, it is expected that the teacher provides additional learning facilities that is the material packaged in the form of video and audio. So that, students who have visual and auditorial learning styles can learn independently by obtaining valid material from the teacher. If it can be done, it will be able to maximize the learning process of sports education because the current generation is familiar to advanced technology.

\section{ACKNOWLEDGMENT}

Thanks to God for being given the guidance, conscience, time, and opportunity to write this scientific work. And thanks for being given the path and ease that support for the completion of the article entitled The Role of Blended Learning on Cognitive Step in Education of Sport Teaching by Adjusting The Students' Learnning Style.

Thank you to Dr. Wasis D. Dwiyogo, M.Pd who gives experience about writing good scientific papers. Thanks also to Puri Selfi Cholifah, S.Pd., M.Pd who has motivated writers to write scientific papers.

Thanks to ISPHE 2018 who are willing to accept scientific papers for publication so that his hope of this scientific work can provide benefits to the wider community and become a scientific reference of high education activists, researchers and students.
And do not forget and this is the most important, a thank you to Mr. Sumino and Miss Siti Ngafiyah as parents of writers who have supported and provide the cost so that authors can publish this scientific work.

Thanks to all readers who later made this paper a reference. I hope hopefully useful.

\section{REFERENCES}

[1] S. Alrabah, S. Wu, and A. Alotaibi, The learning styles and multiple intelligences of EFL college students in Kuwait, 3rd ed., vol 11. International Education Studies: 2018, p.38-47.

[2] MA. Asiry, Learning styles of dental Students, 7th ed., vol. 1. The Saudi Journal for Dental Research: 2016, pp.13-17.

[3] A. Baidhori, "The Development of Futsal Learning Based on Blended Learning as Well as The Effectiveness Test of Learning Outcomes" unpublished.

[4] RM. Brown and C. Palmer, Auditory-motor learning influences auditory memory for music, 4th ed., vol. 40. Memory \& Cognition: 2012, pp.567578.

[5] KT. Chen, Exploring college students' usage experiences, perceptions and acceptance of mobile English learning in Taiwan, 4th ed., vol. 5. The International Technologi Management Review: 2015, pp.162-171.

[6] L. Dacica, The Formative Role of Physical Education and Sports, 180th ed., Procedia-Social and Behavioral Sciences. 2015, pp.1242-1247.

[7] E. Hubackova, and I. Semradova, Evaluation of Blended Learning, 217th ed., Procedia-Social and Behavioral Sciences: 2016, pp.551-557.

[8] YK. Kim, D. Edens, MF. Iorio, CJ. Curtis, and E. Romero, Cognitive skills development among International student at research universities in United State, 4th ed., vol 5. Journal of International Students: 2015, pp.526-540.

[9] Lalima and KL. Dangwal, Blended Learning: An Innovative Approach, 1st ed., vol. 5. Universal Journal of Educational Research: 2017, pp.129136.

[10] M. Leasa, AD. Corebima, Ibrohim, and H. Suwono, Emotional intelligence among auditory, reading, and kinesthetic learning styles of elementary school students in Ambon-Indonesia, 1st ed., vol 10. International Electronic Journal of Elementary Education: 2017, pp.8391.

[11] H. Makino, C. Ren, H. Liu, AN. Kim, N. Kondapeneni, X. Liu, D. Kuzum, and T. Komiyama, Transformation of cortex-wide emergent properties during motor learning, 94th ed., Neuron Article: 2017, pp.880-890.

[12] L. Marinelli, A. Quartarone, M. Hallett, G. Frazzitta and MF. Ghilardi, The many facets of motor learning and their relevance for Parkinson's disease, 128th ed., Clinical Neurophysiology, 2017, pp.1127-1141.

[13] D. Matukhin, and E. Zhitkova, Implementing Blended Learning Technology in Higher Professional Education, 206th ed., ProcediaSocial and Behavioral Sciences: 2015, pp.183-188.

[14] LPB. Millan, B. Semer, JMDS. Rodrigues, and RJ. Gianini, Traditional Learning and Problem-based Learning: self-perception of preparedness for internship, 58th ed., vol. 5. Rev Assoc Med bras: 2012, pp.594-599.

[15] S. Narayana, W. Zhang, W. Rogers, C. Strickland, C. Franklin, JL. Lancaster, and PT. Fox, Concurrent TMS to the primary motor cortex augments slow motor learning, 85th ed., NeuroImage: 2014, pp.971-984.

[16] AL. Nazarenko, Blended Learning vs Traditional Learning: what wroks? (a case study research), 200th ed., Procedia-Social and Behavioral Seciences: 2015, pp.77-82.

[17] AA. Okaz, Integrating Blended Learning in Higher Education, 186th ed., Procedia-Social and Behavioral Sciences: 2015, pp.600-603.

[18] FM. Putra, "Development of Blended Learning Learning Media for the Subject of Physical Education Sport and Health For Class XI" unpublished.

[19] NAA. Rahman, N. Hussein, and AH. Aluwi, Satisfaction on Blended Learning in a Public Higher Education Institution: What Factors 
Matter?, 211st ed., Procedia-Social and Behavioral Sciences: 2015, pp.768-775.

[20] S. Raibowo, "The Development of Interactive Multimedia Tennis Students of the Department of Physical and Health Education" unpublished.

[21] GH. Rassool, and S. Rawaf, The influence of learning styles preference of undergraduate nursing students on educational outcomes in substance use education, 8th ed., Nurse Education in Practice: 2008, pp.306-314.

[22] M. Sandi, "Development of Learning Badminton Lessons Based Blended Learning" unpublished.
[23] AB. Setyawan, "The Development of Interactive Multimedia Teaching Materials on Swimming Courses for Students of Physical Education and Health State University of Malang" unpublished.

[24] Y. Ugurlu, Utilizing human-computer interaction data to extract user interests from web-based learning system, 4th ed., International Journal of Networked and Distributed Computing: 2013, pp.187-195.

[25] T. Yigit, A. Koyun, AS. Yuksel, and IA. Cankaya, Evaluation of Blended Learning approach in computer engineering education, 141st ed., Procedia-Social and Behavioral Seciences: 2014, pp.807-812. 